\title{
横補強筋量が少ない鉄筋コンクリート柱部材の \\ 圧縮ストラット形状の変化と終局せん断強度 \\ SHEAR STRENGTH OF REINFORCED CONCRETE COLUMNS WITH LOW WEB REINFORCEMENT CONSIDERING COMPRESSIVE STRUT SHAPE
}

\section{日比野 陽*, 久田昌典 ${ }^{* *}$, 篠原保二***, 林 靜雄 $* * * *$ \\ Yo HIBINO, Masanori HISADA, Yasuji SHINOHARA and Shizuo HAYASHI}

\begin{abstract}
Previous research shows the prediction of the shear capacity of column, with low web reinforcement ratios, based on truss and arch mechanism provided by AIJ gives underestimate strengths when consider axial load. In this study, experimental tests were conducted to evaluate the effect of axial force on ultimate shear strength calculated based on arch and truss mechanisms concept having specimens with low web reinforcement. From the experimental tests, the following conclusions were obtained: 1) the angle and width of compressive strut decrease and increase with an increase of axial load, respectively; 2) the estimation of column shear capacity including an increase of axial force was determined by modifying the shape of compressive strut; 3) the recent formula shows a good agreement with previous research results by using proposed factor of effectiveness concrete compressive strength; 4) the shear strength contributed from truss mechanism was not influenced by an increasing of axial load.
\end{abstract}

Keywords: Axial force, Ultimate shear strength, Neutral axis, Truss and arch mechanism, Compressive strut, Effectiveness compressive strength factor 軸力, 終局せん断強度, 中立軸, トラス・アーチ機構, 圧縮ストラット, 圧縮強度有効係数

\section{1.はじめに}

鉄筋コンクリート柱梁部材のせん断強度を理論的に求める方法と して,「鉄筋コンクリート造建物の勒性保証型而震設計指針・同解説 1)」（以下，勒性指針）では，トラス・アーチ理論に基づくせん断強 度式（以下，勒性指針式）が示されている。柱と梁のせん断強度を 評価可能であるとされているが，圧縮軸力によるせん断強度の上昇 は式中において考慮されておらず，また，せん断補強筋量が少ない 場合において実験值に対して過大な安全率を与える傾向がある 22こ とが指摘されている。

瀧口ら ${ }^{3)}$ はせん断補強筋を配筋せず，主筋の付着を除去し，せん 断補強筋や主筋の付着による斜め圧縮力伝達をなくした試験体を用 いて,アーチ機構のコンクリートの圧縮力伝達能力の把握を行い, 実験結果の下限值からアーチ機構発生時のコンクリート有効圧縮強 度 $\left(v_{0} \sigma_{B}\right)$ を直接的に求めている。軸力により部材端部の圧壊が生じ, 破壞形式が変化するため，最大耐力に影響を及ぼすと述べている。 白石ら ${ }^{4)}$ はせん断補強筋がない試験体および，主筋の付着がない試 験体の解析結果から, 軸力が大きいほど, 解析で求めたせん断強度 が勒性指針式による計算値を上回ることを指摘している。軸力が大 きくなるとトラス機構の角度は大きくなり，勒性指針式の上限の角 度である 45 度を上回ることから,このときのコンクリート圧縮強度
有効強度係数 $v_{0}$ は軸力比 $\eta$ によって異なると述べている。

図 1 は既往の文献 ${ }^{5)-27}$ から得られた柱試験体のせん断破壊時の最 大耐力值 $Q_{\max }$ と勒性指針式 $V_{u}$ および,「鉄筋コンクリート構造計算 規準・同解説 ${ }^{28)} 」$ における下式のせん断強度式 $Q_{s u}$ (以下，規準式） の比と軸力比の関係を示したものである。図中の点種の違いは横補 強筋量 $\left(p_{w e} \sigma_{w y} / v_{0} \sigma_{B}\right)$ を表し, 実線は全プロットの回帰直線である。

$$
Q_{s u}=\left\{\frac{0.052 p_{t}^{0.23}\left(18+\sigma_{B}\right)}{M /(Q d)+0.12}+0.85 \sqrt{p_{w} \sigma_{w y}}+0.1 \sigma_{0}\right\} b j
$$

ここに, $p_{t}$ : 引張鉄筋比 $(\%), \sigma_{B}$ : コンクリート圧縮強度, $M /(Q d)$ : せん断スパン比, $p_{w}$ : せん断補強筋比 $\left(=a_{w} /(b \cdot s)\right), \sigma_{w y}$ : せん断補強筋 の降伏強度, $\sigma_{0}$ : 軸方向応力度 $(=N /(B D)), b$ : 部材幅, $j:$ 応力中心 間距離 $(=7 / 8 d)$

図 1(a)の規準式によるせん断強度は実験值と精度良く一致してい る。回帰直線は軸力比の増大に伴い小さくなるが，ほぼ 1 となる。 また，横補強筋量の大小に関わらずせん断強度は実験值と一致して いる。一方，勒性指針式によるせん断強度は軸力比の増大とともに 実験值を過小評価寸る（図 1(b)）。特に，軸力比が大きい場合におい て，実験值を 2 倍程度過小評価するものが多く，横補強筋量が小さ いほどその傾向が大きい。これは，勒性指針式において軸力による

\footnotetext{
**東京工業大学応用七ラミックス研究所 助教・博士 (工学)

** 鹿島建設侏) 修士(工学)

*** 東京工業大学建築物理研究センター 准教授・工博

**** 東京工業大学応用セラミックス研究所 教授・工博

Assist. Prof., Materials and Structures Laboratory, Tokyo Institute of Technology, Dr. Eng. Kajima Corporation, M. Eng.

Assoc. Prof., Structural Engineering Research Center, Tokyo Institute of Technology, Dr. Eng. Prof., Materials and Structures Laboratory, Tokyo Institute of Technology, Dr. Eng.
} 
せん断力上昇の効果が横補強筋比の小さい範囲で現れることを示唆 している。

そこで本研究では, 勒性指針式におけるトラス・アーチ機構に及 ぼす圧縮軸力の影響を明らかにするため, 一定軸力を与えたせん断 補強筋量が少ない試験体の載荷実験を行い, 圧縮ストラット形状の 変化に着目することで, 軸力による耐力上昇の影響を考慮したせん 断強度評価式の提案を行う。筆者らは既往の文献 ${ }^{29}$ において勒性指 針式に基づく軸力の影響を考慮したせん断強度式を提案しているが， 力学的な釣り合いや式の連続性が失われているものであった。本稿 ではそれらを修正するとともに，既往の文献との比較による検討を 加えた新たなせん断強度式を提案する。以降，本稿で述べる軸力と は圧縮軸力のことを表す。

\section{2. トラス・アーチ機構に基づくせん断強度評価式}

トラス・アーチ機構に基づくせん断強度は勒性指針から下式(2) 〜 (4)による值のうちの最小値で表される。

$$
\begin{aligned}
& V_{u}=\mu p_{w e} \sigma_{w y} b_{e} j_{e}+\left(v \sigma_{B}-\frac{5 p_{w e} \sigma_{w y}}{\lambda}\right) \frac{b D}{2} \tan \theta \\
& V_{u}=\frac{\lambda v \sigma_{B}+p_{w e} \sigma_{w y}}{3} b_{e} j_{e} \\
& V_{u}=\frac{\lambda v \sigma_{B}}{2} b_{e} j_{e}
\end{aligned}
$$

ここに, $\mu$ : トラス機構の角度を表す係数 $\left(=\cot \phi, 2-20 R_{p}\right), R_{p}$ : 終局 限界状態でのヒンジ領域の回転角, $p_{w e}$ : 有効補強筋比, $\sigma_{w y}$ : 横補強 筋の信頼強度, $b_{e}$ : トラス機構に関与寸る断面の有効幅, $j_{e}$ : トラス 機構に関与する断面の有効せい, $v$ : コンクリート圧縮強度の有効係 数 $\left(=\left(1-20 R_{p}\right) v_{0}\right), v_{0}$ ：降伏ヒンジ・潜在ヒンジを計画しないときの有 効係数 $\left(=0.7-\sigma_{B} / 200\right), \sigma_{B}$ : コンクリートの圧縮強度, $\lambda$ : トラス機構 の有効係数, $b$ : 断面幅, $D$ : 断面せい, $\theta:$ アーチ機構の圧縮束の 角度

図 2 に前述の 3 式と横補強筋量の関係を示す。図中の (2) (6)は式 番号を表し，(5)，(6)はトラス機構による負担せん断力 $V_{t}$ として，そ れぞれ下式で表される。

$$
\begin{aligned}
& V_{t}=p_{w e} \sigma_{w y} b_{e} j_{e} \sqrt{\frac{\lambda v_{0} \sigma_{B}}{p_{w e} \sigma_{w y}}-1} \\
& V_{t}=2 p_{w e} \sigma_{w y} b_{e} j_{e}
\end{aligned}
$$

$p_{w e} \sigma_{w y} / \nu_{0} \sigma_{B} \leq \lambda / 5$ の範囲にあっては, アーチ機構が生じるため, せん 断強度式は OCAB となる。図 1 で示した横補強筋量が小さい場合と

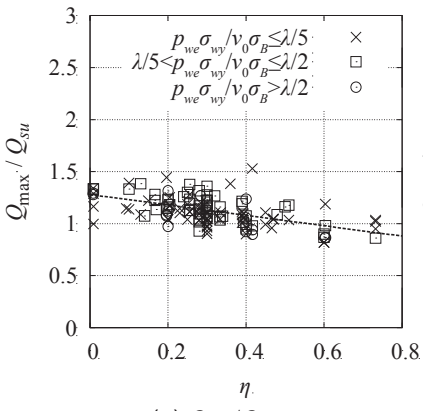

(a) $Q_{\max } / Q_{s u}$

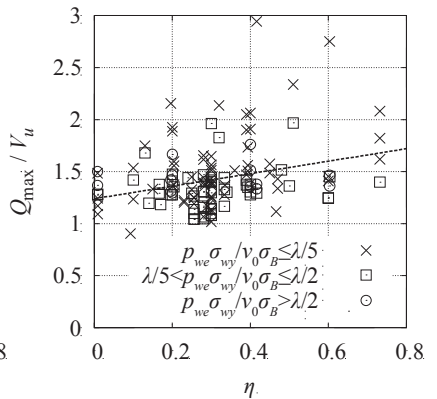

(b) $Q_{\max } / V_{u}$
図 1 せん断強度と軸力比 $\eta$
は, 主にはこの範囲のことであり, 軸力によるせん断力の上昇が顕 著であったことから，アーチ機構の負担せん断力が上昇しているこ とが考えられる。すなわち, 図 2 中の実線 OCAB で表されるせん断 強度式がアーチ機構の負担せん断力の上昇により, 実線 ODAB に変 化していることが予想される。よって, 軸力下における試験体のせ 几断強度から一点鎖線 DA が求まればアーチ機構の負担せん断力の 増加分を求めることが可能になると考えられる。

\section{3. 実験概要}

\section{1 試験体}

本研究では軸力によるせん断力上昇を考察するための試験体とし て全部で 4 シリーズ, 計 18 体を作製した。アーチ機構を考察するた めの試験体シリーズ $\mathrm{A} 1$ 〜 4 と，トラス機構を考察するためのシリ ーズ $\mathrm{T}$ である。図 3 に試験体配筋図, 表 1 に試験体一覧を示す。表 1 中の曲げ終局強度 $Q_{m u}$ は平面保持を仮定した断面の釣り合いから 主筋の降伏より先にコンクリートの圧壊が生じて終局に至るという 条件の時の曲げモーメントにより算出した值である。

試験体の断面は $\mathrm{A} 1 \sim \mathrm{A} 4$ シリーズで $b \times D=120 \times 200(\mathrm{~mm}), \mathrm{T}$ シリー ズで $b \times D=180 \times 250(\mathrm{~mm})$ である。A1〜A4 シリーズ試験体の主筋には 付着力がせん断強度に及ぼす影響を排除するため, 試験区間の付着 を除去したアンボンド PC 鋼棒 $(\phi 13, \mathrm{SBPR} 1090)$ を用い，せん断補強

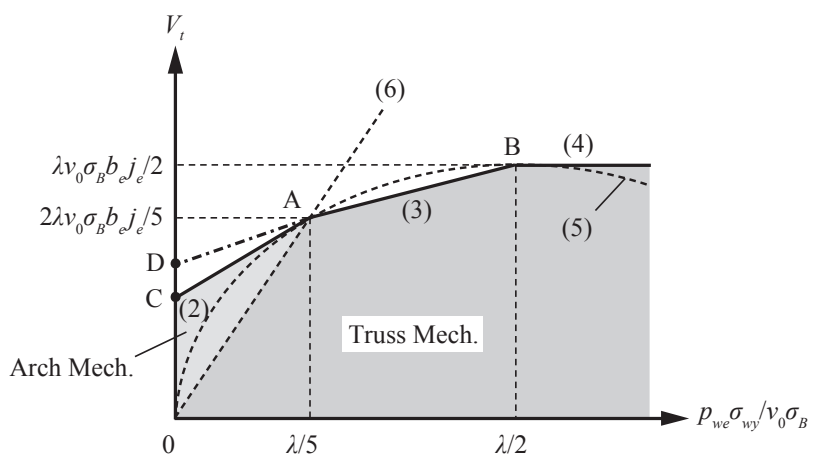

図 2 横補強筋量とせん断強度

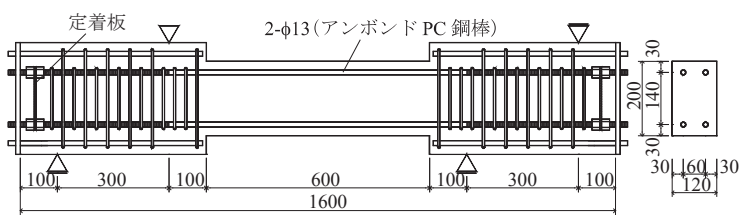

(a) A1, A2, A3 シリーズ試験体

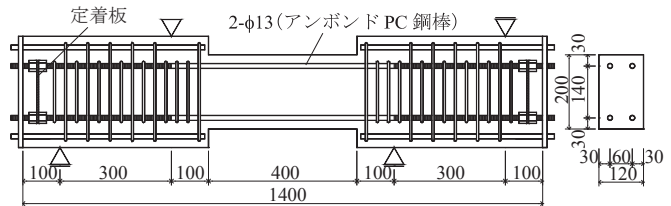

(b) A4 シリーズ試験体

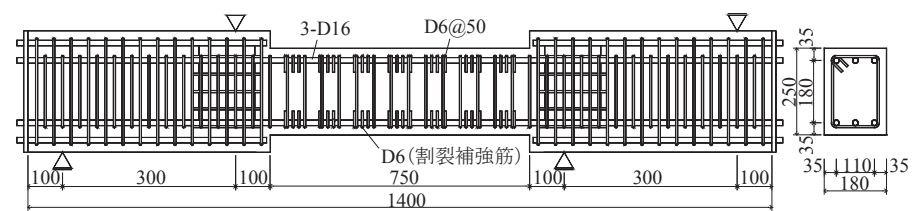

(c) $\mathrm{T}$ シリーズ試験体

図 3 試験体配筋図 
表 1 試験体詳細

\begin{tabular}{|c|c|c|c|c|c|c|c|c|c|c|c|c|c|c|c|c|c|c|c|}
\hline シリーズ & 試験体名 & $\begin{array}{c}b \\
(\mathrm{~mm})\end{array}$ & $\begin{array}{c}D \\
(\mathrm{~mm})\end{array}$ & $\begin{array}{c}L \\
(\mathrm{~mm})\end{array}$ & $M / Q D$ & $\begin{array}{c}F_{c} \\
\left(\mathrm{~N} / \mathrm{mm}^{2}\right)\end{array}$ & 主筋 & $\begin{array}{l}\text { せん断 } \\
\text { 補強筋 }\end{array}$ & $\begin{array}{c}p_{w e} \sigma_{w y} \\
/ v_{0} \sigma_{B}\end{array}$ & $\begin{array}{c}\text { 軸力比 } \\
\eta\end{array}$ & $\begin{array}{c}V_{s c} \\
(\mathrm{kN})\end{array}$ & $\begin{array}{c}V_{s c \text { min }} \\
(\mathrm{kN})\end{array}$ & $\begin{array}{c}V_{u} \\
(\mathrm{kN})\end{array}$ & $\begin{array}{l}V_{u 0} \\
(\mathrm{kN})\end{array}$ & $\begin{array}{l}Q_{m u} \\
(\mathrm{kN})\end{array}$ & $\begin{array}{l}Q_{\max } \\
(\mathrm{kN})\end{array}$ & $\begin{array}{l}R_{\max } \\
(\mathrm{rad})\end{array}$ & $\begin{array}{c}Q_{b u} \\
(\mathrm{KN})\end{array}$ & $\begin{array}{l}\text { 破壊 } \\
\text { 形式 }\end{array}$ \\
\hline \multirow{4}{*}{ A1 } & A1-0 & \multirow{15}{*}{120} & \multirow{15}{*}{200} & \multirow{11}{*}{600} & \multirow{11}{*}{1.5} & \multirow{4}{*}{30} & \multirow{15}{*}{$\begin{array}{c}4-\phi 13 \\
\left(p_{t}=1.11 \%\right)\end{array}$} & \multirow{15}{*}{-} & \multirow{15}{*}{0} & 0 & 42.4 & 21.6 & \multirow{4}{*}{32.2} & \multirow{4}{*}{57.1} & 59.8 & 48.6 & 0.015 & 52.0 & $\mathrm{FC}$ \\
\hline & A1-2 & & & & & & & & & 0.2 & 76.0 & 38.8 & & & 57.2 & 59.8 & \begin{tabular}{|l|}
0.011 \\
\end{tabular} & 47.7 & $\mathrm{FC}$ \\
\hline & A1-4 & & & & & & & & & 0.4 & 98.7 & 50.4 & & & 56.7 & 64.7 & 0.007 & 58.1 & $\mathrm{FC}$ \\
\hline & A1-6 & & & & & & & & & 0.6 & 117.1 & 59.7 & & & 46.4 & 71.6 & 0.005 & 63.0 & $\mathrm{FC}$ \\
\hline \multirow{3}{*}{ A2 } & A2-0 & & & & & \multirow{3}{*}{80} & & & & 0 & 76.3 & 38.9 & \multirow{3}{*}{63.2} & \multirow{3}{*}{156.2} & 144.3 & 85.1 & 0.022 & 87.7 & $\mathrm{FC}$ \\
\hline & A2-2 & & & & & & & & & 0.2 & 159.4 & 81.3 & & & 143.6 & 109.8 & 0.009 & 96.8 & FC- $>$ ST \\
\hline & A2-4 & & & & & & & & & 0.4 & 212.1 & 108.2 & & & 146.9 & 123.2 & 0.004 & 128.2 & DT \\
\hline \multirow{4}{*}{ A3 } & A3-0 & & & & & \multirow{4}{*}{120} & & & & 0 & 108.0 & 55.1 & \multirow{4}{*}{83.0} & \multirow{4}{*}{234.5} & 194.3 & 101.1 & 0.017 & 96.4 & \begin{tabular}{|l|}
$\mathrm{FC}$ \\
\end{tabular} \\
\hline & A3-2 & & & & & & & & & 0.2 & 230.8 & 117.7 & & & 201.6 & 144.1 & 0.008 & 141.8 & FC->ST \\
\hline & A3-4 & & & & & & & & & 0.4 & 308.0 & 157.1 & & & 211.9 & 161.4 & 0.004 & 195.3 & \begin{tabular}{|l|} 
DT \\
\end{tabular} \\
\hline & A3-6 & & & & & & & & & 0.6 & 369.5 & 188.4 & & & 163.8 & 148.2 & 0.002 & 183.7 & DT \\
\hline \multirow{4}{*}{ A4 } & A4-0 & & & \multirow{4}{*}{400} & \multirow{4}{*}{1} & \multirow{4}{*}{30} & & & & 0 & 39.5 & 20.2 & \multirow{4}{*}{45.5} & \multirow{4}{*}{79.6} & 86.6 & 78.2 & 0.011 & 78.6 & FC->ST \\
\hline & A4-2 & & & & & & & & & 0.2 & 71.5 & 36.5 & & & 82.8 & 94.0 & 0.008 & 97.3 & FC->ST \\
\hline & A4-4 & & & & & & & & & 0.4 & 93.1 & 47.5 & & & 81.9 & 75.4 & 0.002 & 103.4 & \begin{tabular}{|l|} 
DT \\
\end{tabular} \\
\hline & A4-6 & & & & & & & & & 0.6 & 110.6 & 56.4 & & & 67.1 & 71.6 & 0.001 & 97.4 & DT \\
\hline
\end{tabular}

$b$ : 部材幅, $D$ : 部材せい, $L$ : 部材長さ, $L / 2 D$ : せん断スパン比, $\sigma_{B}$ : コンクリート圧縮強度, $\sigma_{T}$ : 引張強度, $p_{t}$ : 引張主筋比 $\left(a /(b \cdot D), a_{t}\right.$ : 引張主筋の断面積, $\sigma$ :

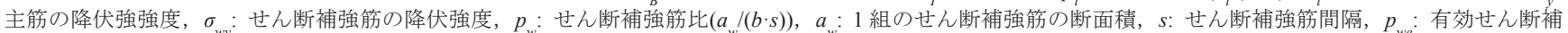
強筋比 $\left(a_{w} /(b \cdot s)\right), \quad b$ : ト ト ラ機構に関与寸る断面の有効幅, $v_{0}$ : コンクリート圧縮強度の有効係数 $\left(1.72 \sigma_{B}^{-0.33}\right), \lambda:$ トラス機構の有効係数 $\left(1-s /\left(2 j j_{e}\right)-b /(4 j)\right), j_{e}:$ ト ラス機構に関与する断面の有効せい, $b$ : せん断補強筋の断面方向の間隔, $V:$ : せん断ひび割れ強度 $\left(=b d \sigma_{t}\left(1+\sigma_{0} / \sigma_{t}\right)^{0.5} / 1.5\right), V:$ 鞋性指針による終局せん断強度, $V_{u 0}: v_{0}=0$ としたときの勒性指針式, $Q_{m u}$ : 曲げ終局時せん断力, $Q_{\text {max }}$ : 最大耐力, $R_{\text {max }}$ : 最大耐力時変形角, $Q_{b u}$ : 実験の計測值をもとに, 応力ブロックを仮定し て計算したコンクリート圧壊時の曲げ強度, 破壊形式: 端部コンクリート圧縮破壞(FC); せん断引張破壞(ST); せん断斜張力破壊(DT)

筋を配さないことで, アーチ機構のみが出現するようにした ${ }^{3)}$ 。主 筋の付着を除去することで, アーチ機構の形状変化により, ひび割 れや破壊状況が変化し, 安全側のアーチ機構強度を与える可能性も ある ${ }^{30), 311}$ が，アーチ機構を把握しやすくするために使用した。T シ リーズ試験体の主筋には D16 の高強度鉄筋(USD980)を用い, トラス 機構における軸力の影響を検討するため， $p_{w e} \sigma_{w y} / v_{0} \sigma_{B}$ が $\lambda / 5$ （軸力が ない場合にトラス機構が全せん断力を負担する最小補強筋量）程度 となるようにせん断補強筋を配筋した。付着割裂破壊を防止するた めの割裂補強筋も配筋した。A 1 A 4 シリーズ試験体のコンクリー 卜強度は $30,80,120\left(\mathrm{~N} / \mathrm{mm}^{2}\right)$ を目標とし, 軸力比 $(\eta=0,0.2,0.4,0.6)$ の 異なる試験体として各シリーズ 4 体ずつ作製した。せん断スパン比 は A4 シリーズ試験体のみ 1.0 とし，A1〜A3 シリーズ試験体は 1.5 とした。 Tシリーズ試験体のコンクリート強度は $30\left(\mathrm{~N} / \mathrm{mm}^{2}\right)$ を目標 として, 軸力比 0 と 0.3 の試験体を作製した。せん断スパン比は 1.5 としている。試験体に用いた鉄筋とコンクリートの材料特性を表 2 , 3 に示す。

全試験体ともせん断破壊先行型として設計し, 終局曲げ強度 $Q_{m u}$ が勒性指針式によるせん断強度 $V_{u}$ を上回るように設計した。参考と してせん断ひび割れ強度 $V_{s c}, V_{s \mathrm{~min}}$ も示した。表中の $V_{u 0}$ はコンクリ 一下圧縮強度有効係数 $v_{0}$ を 1 とした場合の終局せん断強度である。

\section{2 載荷方法}

図 4 に載荷装置図を示す。試験体はローラー支承とピン支承で支 持する。試験体両側に配した反力用の鉄骨ブロックを試験体両側面 に配置した鉄骨梁で接続し，試験体片側（図中左側）に半球座を介 して固定したジャッキにより，軸力を与えた。

試験体上部の載荷装置によって鉄骨梁を介して逆対称形式になる ようせん断力を与え, 一方向単調載荷を行った。載荷は, せん断ひ び割れが発生した試験体においては発生直後まで，せん断ひび割れ が発生しなかった試験体では, 最大耐力以後, せん断力が最大耐力 の $80 \%$ に低下した時点まで行った。
表 2 鉄筋の材料特性

\begin{tabular}{|c|c|c|c|c|c|c|}
\hline 呼び名 & 規格 & $\begin{array}{c}\text { 降伏応力度 } \\
\sigma_{y}\left(\mathrm{~N} / \mathrm{mm}^{2}\right)\end{array}$ & $\begin{array}{c}\text { 降伏歪 } \\
\varepsilon_{y}(\mu)\end{array}$ & $\begin{array}{c}\text { 最大応力度 } \\
\sigma_{t}\left(\mathrm{~N} / \mathrm{mm}^{2}\right)\end{array}$ & $\begin{array}{c}\text { 弾性係数 } \\
E_{s}\left(\mathrm{~N} / \mathrm{mm}^{2}\right)\end{array}$ & $\begin{array}{c}\text { 伸び率 } \\
(\%)\end{array}$ \\
\hline D6 & SD295A & 365 & 3732 & 513 & $2.11 \times 10^{5}$ & 23.3 \\
\hline$\phi 13$ & SBPR1090 & 1183 & 11200 & 1283 & $1.95 \times 10^{5}$ & 11.2 \\
\hline D16 & USD980 & 1072 & 7190 & 1143 & $2.02 \times 10^{5}$ & 7.8 \\
\hline
\end{tabular}

表 3 コンクリートの材料特性

\begin{tabular}{|c|c|c|c|c|c|}
\hline シリーズ & $\begin{array}{c}\text { 材齢 } \\
(\text { day })\end{array}$ & $\begin{array}{c}\text { 圧縮強度 } \\
\sigma_{B}\left(\mathrm{~N} / \mathrm{mm}^{2}\right)\end{array}$ & $\begin{array}{c}\text { 圧縮強度時丕 } \\
\varepsilon_{y}(\mu)\end{array}$ & $\begin{array}{c}\text { 弾性係数 } \\
E_{c}\left(\mathrm{~N} / \mathrm{mm}^{2}\right)\end{array}$ & $\begin{array}{c}\text { 引張強度 } \\
\sigma_{t}\left(\mathrm{~N} / \mathrm{mm}^{2}\right)\end{array}$ \\
\hline $\mathrm{A} 1$ & 54 & 29.3 & 1918 & $2.72 \times 10^{4}$ & 2.65 \\
\hline $\mathrm{A} 2$ & 36 & 80.2 & 2781 & $3.52 \times 10^{4}$ & 4.77 \\
\hline $\mathrm{A} 3$ & 42 & 120.4 & 3109 & $4.42 \times 10^{4}$ & 6.75 \\
\hline $\mathrm{A} 4$ & 40 & 28.1 & 1702 & $2.68 \times 10^{4}$ & 2.47 \\
\hline $\mathrm{T}$ & 68 & 33.2 & 1909 & $2.70 \times 10^{4}$ & 2.86 \\
\hline
\end{tabular}

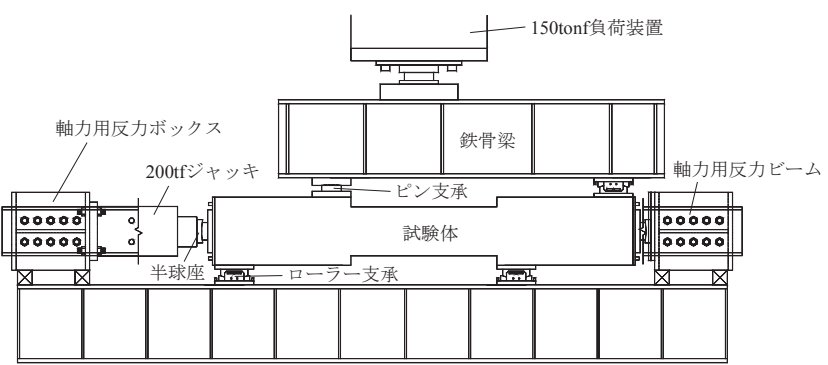

図 4 載荷装置図

\section{4. 実験結果}

\section{1 最終破壊状況}

図 5 に各試験体の最終破壊状況を示す。破壊形式は表 1 中に示し た。破壊形式は曲げ圧縮破壊( $\mathrm{FC})$, せん断引張破壊( $\mathrm{ST})$, せん断斜 張力破壊(DT) と分類した。曲げ圧縮破壊とは，曲げ変形の卓越によ り，危険断面の端部のコンクリートが圧壊し，耐力が低下し，終局 に至る破壊形式である。せん断引張破壊とは，せん断ひび割れが生 


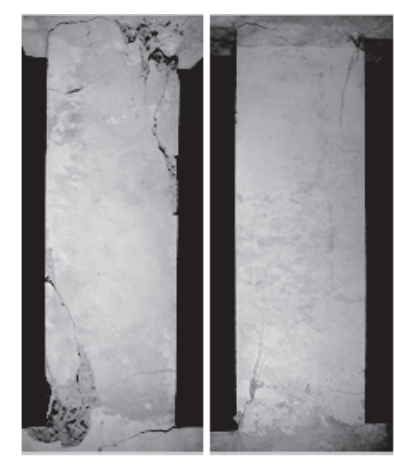

A1-0 $(\eta=0.0)$

(a) A1 シリーズ

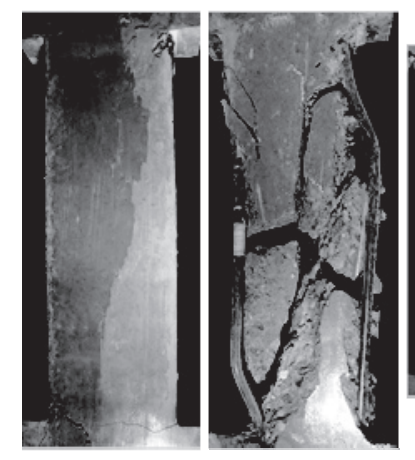

A3-0 $(\eta=0.0)$

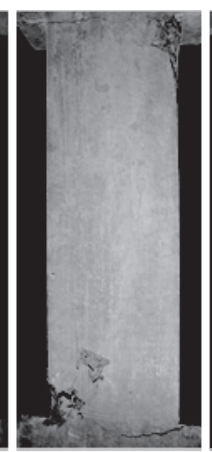

A2-0 $(\eta=0.0)$

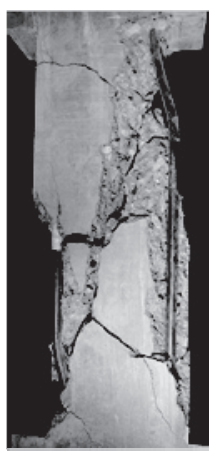

A2-6 $(\eta=0.6)$ (b) A2 シリーズ

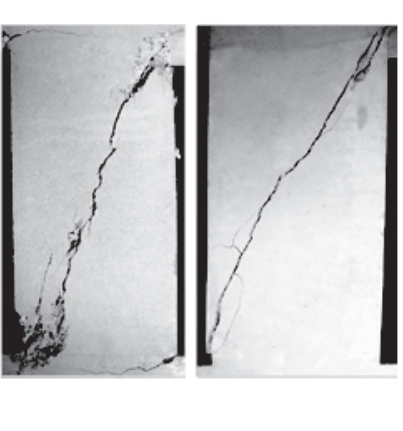

A4-0 $(\eta=0.0)$

(d) A4 シリーズ

(c) A3 シリーズ

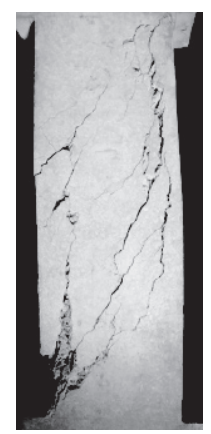

$\mathrm{T}-0(\eta=0.0)$

(e) T シリーズ

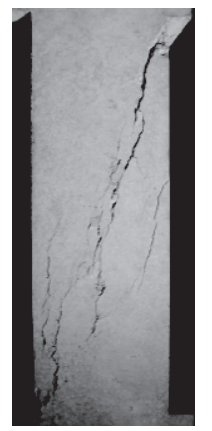

$\mathrm{T}-3(\eta=0.3)$

図 5 最終破壊状況

じた後, ひび割れ幅の増大により耐力が低下し，終局に至る破壊形 式である。せん断斜張力破壊はせん断ひび割れ発生と同時に耐力が 急激に低下し, 終局に至る破壊形式である。各試験体の破壊形式は 計算した各強度による比較に加え, 終局強度と破壊状況およびせん 断ひび割れ強度, 次節で示すせん断力ー変形角関係および曲げ圧縮 破壊時の強度 $Q_{b u}$ によって判別した。基本的にはせん断ひび割れ強 度 $V_{s c}$ よりも小さい荷重で破壊した試験体はせん断斜張力破壊とし, それ以外は曲げ圧壊あるいは曲げ圧壊後のせん断引張破壊とした。

$\mathrm{A} 1$ シリーズでは, 全ての試験体が曲げ圧縮破壊により終局に至っ た（図 5(a))。軸力が大きいほど, かぶりコンクリートがほとんど剥 落せず，かつ大きな曲げひび割れが生じないまま終局に至った。い ずれの試験体においても顕著なせん断ひび割れは確認できなかった。 一方, A2, A3, A4 シリーズでは, 軸力比によって破壊形式が異なっ た。軸力比が比較的小さい場合には, 曲げ圧縮破壊により終局に至
ったが，軸力比が大きくなるとせん断斜張力破壊により終局に至っ た（図 5(b)(c)(d)）。A2-2, A3-2, A4-0, A4-2 試験体については, 端部 コンクリート圧壊後に部材の対角方向に沿ったせん断ひび割れが生 じて終局に至った。A2-4, A2-6, A3-4, A3-6, A4-4, A4-6 試験体ではひ び割れ発生と同時に荷重が急激に低下し, 脆性的な破壊性状を呈し た。 T シリーズの試験体 T-0 では, 端部コンクリートの圧壊が生じ た後, せん断引張破壊して終局に至り, T-3 試験体はせん断引張破 壊を生じて終局に至った（図 5(e)）。

\section{2 せん断カー変形角関係}

図 6 に各シリーズのせん断力ー変形角関係を示す。図中の×印は せん断ひび割れ発生時の点である。

$\mathrm{A} 1$ シリーズの試験体 A1-0 の最大耐力は $V_{u}$ を大きく上回り，せん 断ひび割れ強度 $V_{s c}$ とほぼ同じになった。A 1 シリーズのその他の試 験体の最大耐力は軸力の増加に伴い大きくなり, コンクリート圧縮 強度の有効係数 $v_{0}$ を 1 として計算したせん断強度 $V_{u 0}$ をも上回った。 A1-6 試験体は勒性指針式のせん断強度 $V_{u}$ の 2 倍以上となった。A2, $\mathrm{A} 3, \mathrm{~A} 4$ シリーズにおいても, 最大耐力は軸力の増加に伴い大きくな った。A4 シリーズでは A4-0 試験体の最大耐力が $V_{u 0}$ とほぼ同值と なり， $V_{u}$ を大きく上回った。曲げ圧縮破壊となった試験体の勒性能 は非常に大きく, 変形角 1/50 程度まで耐力を保っていたが, コンク リート強度, 軸力比が共に大きい試験体である A3-6, A4-4, A4-6 試 験体は他の試験体に見られた軸力に伴う最大耐力の上昇が見られず， 脆性的な破壊性状を示した。

最大耐力值がせん断強度 $V_{u}$ よりも大きいにも関わらず, 上記のよ うな曲げ圧縮破壊が生じた理由として, 主筋に付着がないことが原 因であると考えられる。文献 31), 32)において, 主筋付着がない場合 には部材中央部におけるせん断力の伝達が小さくなり, 端部にひび 割れが集中することが示されており, 本稿の試験体においても同様 の状態であったと推察される。

そこで，コンクリート圧壊時の終局曲げ耐力の計算を行い，実験 值と比較を行った。最大耐力時におけるコンクリート曲げ圧壊時の せん断力 $Q_{b u}$ の計算值と実験值の比較を図 7(a)に示す。最大耐力時 の平面応力状態は付着がないことを考慮して, 図 7(b)のとおり仮定 した。圧縮側のコンクリートには $\mathrm{ACI}$ 規準 ${ }^{32)}$ の応力ブロックを仮定 し， $T_{s}$ には計測されたひずみデータを元に計算した PC 鋼棒 4 本の 軸力を用いた。なお, 軸力の大きな試験体においては, 圧縮ひずみ が計測されていた。また, コンクリートの圧縮領域の係数 $\beta_{1}$ は $\mathrm{ACI}$ 規準 ${ }^{32)}$ に準じてコンクリート強度により变動させた (0.85-0.05( $\left.\sigma_{B} \times 9.8-280\right) / 70: \mathrm{A} 1, \mathrm{~A} 4$ シリーズ, $0.65: \mathrm{A} 2, \mathrm{~A} 3$ シリーズ)。 図 7(a)の白抜き印は表 1 の破壊形式において「FC」または「FC $\rightarrow \mathrm{ST} 」$, 黒塗り印は「DT」と判定した試験体である。曲げ圧壊と判定した試 験体の実験值はいずれも計算值を上回っており，曲げ圧壊したと考 えられる。また, 斜張力破壊と判定された試験体の実験值はいずれ も計算值より小さく, 曲げ強度に達する前にせん断破壊したと考え られる。

以上から，端部コンクリートの圧壊で終局に至った試験体におけ る軸力上昇による耐力の上昇は, 曲げ変形に伴うものであったと考 えられ, 結果として, 最大耐力值は勒性指針式のせん断強度を大き く上回ったと考えられる。これにより, コンクリート圧縮強度の有 効係数を 1 にした場合のせん断耐力 $V_{u 0}$ を上回ったと説明できる。 


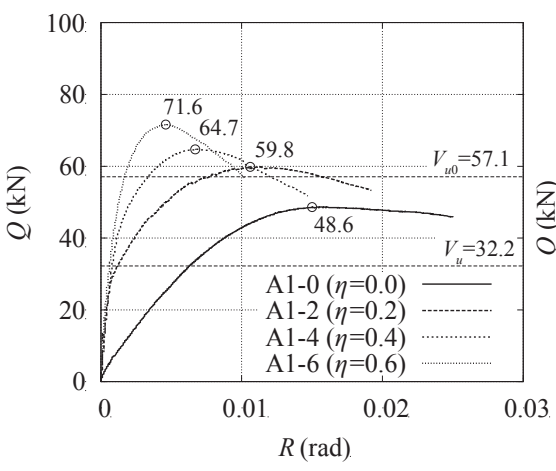

(a) A1 シリーズ

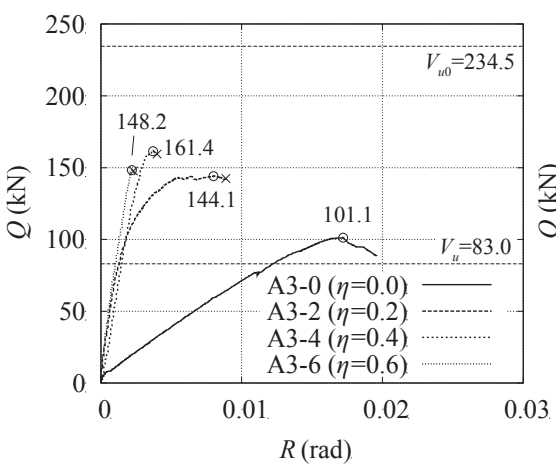

(c) A3 シリーズ

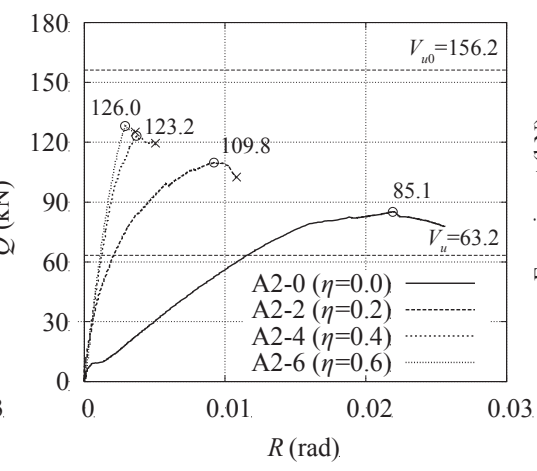

(b) A2 シリーズ

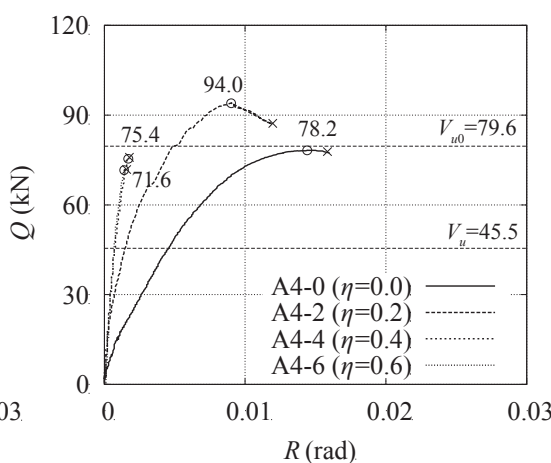

(d) A4 シリーズ

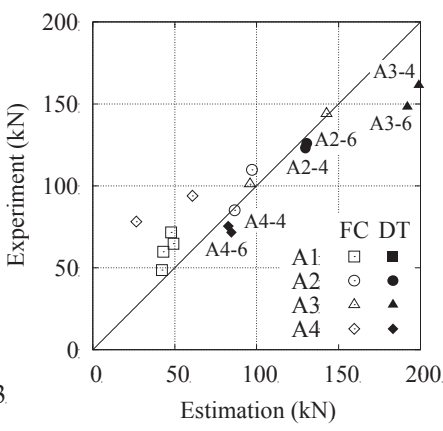

(a) 曲代圧壊強度計算値

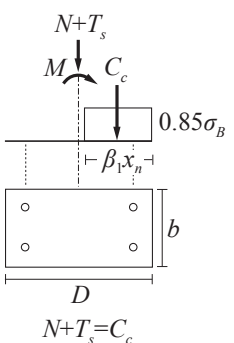

(b) 最大耐力時 平面応力状態

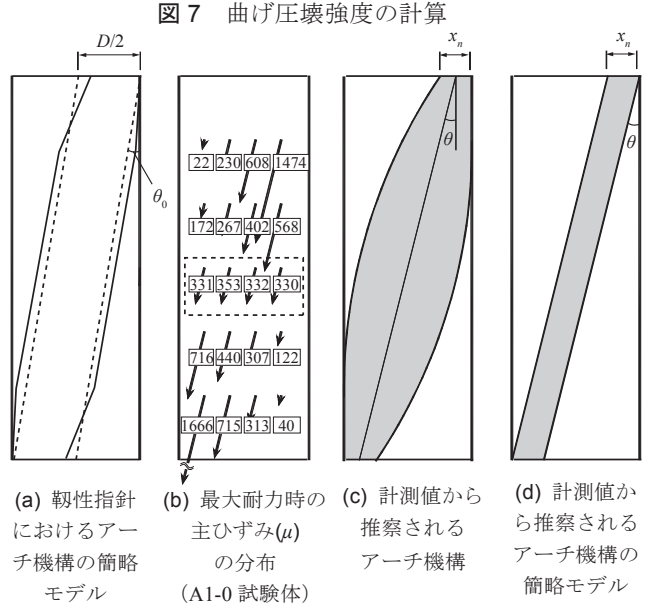

図 8 圧縮ストラットの形状

図 6 せん断力一変形角関係

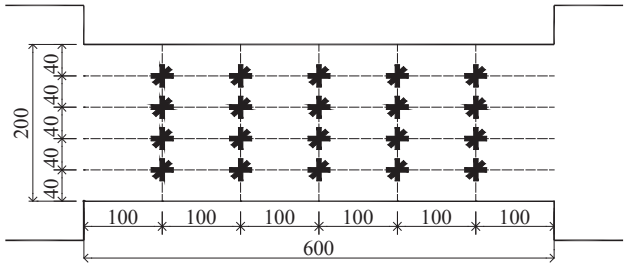

図 93 軸ひずみゲージ貼付位置（A1 シリーズ試験体）

\section{5. 軸力を受ける時のアーチ機の負担せん断強度}

\section{1 圧縮ストラットの形状と角度}

靭性指針式におけるアーチ機構の圧縮ストラットの角度は簡略化 され，式(7)によって与えられる。

$$
\tan \theta_{0}=\frac{\sqrt{L^{2}+D^{2}}-L}{D}
$$

ここに, $L:$ 部材長さ $, D:$ 断面せい

このときの圧縮ストラットの見付け幅は部材せい $D$ の $1 / 2$ で簡略化 されており(図 8 参照), 部材のせん断スパン比によって決定される。 勒性指針において軸力を受ける部材のストラット形状の変化につい ては言及されていないが，軸力の増大によりコンクリートの圧縮力 も増大寸ることから，圧縮ストラットの形状はトラス機構のストラ ットと同様に, 軸力の増大に伴い変化すると考えられる ${ }^{33)}$ 。本研究 では, A1 シリーズ試験体に 3 軸ひずみゲージ(図 9 参照)を貼付し， 最大耐力時の主ひずみにより, 圧縮ストラットの形状を求めた。た だし，圧縮領域の見付け幅を直接求めることは困難であるため，花 井らの研究 ${ }^{34)}$ と同様に部材端部の圧縮縁から中立軸までの距離 $x_{n}$ を求めた。なお, 曲げ圧壊した試験体は純粋なせん断破壊とはなっ ていないため, アーチ機構に関して論ずることは必ずしも的確では ないと言えるが，アーチ機構が形成された上で曲げ圧壊が生じてい ると考えることができるため, アーチ機構への軸力の影響は評価可 能であると考えた。
圧縮ストラットの求め方は, 1) 圧縮ストラットの角度を仮定する (最初は勒性指針式により求められる角度 $\theta_{0}$ を仮定した)。2) 仮定 した角度での圧縮ストラットを描画し，ストラット上に存在する 3 軸のひずみゲージの主ひずみ角度の平均值を求める（圧縮ストラッ トの対角は必ず部材の対角に一致することとする）。3）主ひずみか ら求めた圧縮ストラットの角度と比較し, 角度が一致しなければ 1) 〜3)を繰り返す。角度が一致した時の角度と形状を圧縮ストラット の角度と形状とした。図 10 に実験から得られたストラットの形状と 角度を示す。図中の矢印の長さと方向が主ひずみの大きさと方向を 表し, 矢印の出発点がゲージ位置を表す。灰色部分は勒性指針によ って求められるストラット形状であり, 濃い灰色部分が本実験より 求められたストラット形状である。

実験より得られた圧縮ストラットの角度 $\theta$ は, 軸力ゼロの A1-0 試験体では鞋性指針式により求めた角度 $\theta_{0}$ より大きく, ストラット の形状は勒性指針式よりも細くなり, それに伴い中立軸位置 $x_{n}$ も小 さくなった（図 10(a)）。軸力比 $\eta=0.2$ の A1-2 試験体（図 10(b)）の み他とは形状が細く, 異なっているが，圧縮ストラットの角度は軸 力の増加に伴い勒性指針式の角度に近くなり , 軸力比 $\eta=0.6$ の A1-6 
試験体（図 10(d)）では勒性指針式の角度 $\theta_{0}$ より小さくなった。ス トラットの形状も軸力の増大に伴い太くなった。

勒性指針による圧縮ストラットは, 図 8(a)に示すように, 中央部 が膨らんだ形となるが，負担せん断力は中央の形状によらず，部材 中央の有効圧縮強度 $v_{0} \sigma_{B}$ によって決定されるため, 直線的に表現さ れた簡略モデルを用いた。図 8(b)の主ひずみ（図中の数值）は端部 の圧縮域ほど大きくなっており, 破線で囲まれた中央部での主ひず みの大きさはほぼ等しかった。中央部のひずみから算出したコンク リートの圧縮応力度は平均で $9.15 \mathrm{~N} / \mathrm{mm}^{2}$ であり, 計算される有効圧 縮強度 $\left(=16.5 \mathrm{~N} / \mathrm{mm}^{2}\right)$ よりもやや小さかったが，図 8(b)の最大耐力時 の主ひずみの分布からストラット中央の膨らむ傾向が確認できたと いえる。

\section{2 中立軸位置}

$\mathrm{A} 1$ シリーズ試験体の圧縮縁から中立軸までの距離 $x_{n}$ を図 11 に示 す。図 11 中の○印は図 10 に示寸圧縮ストラットの角度から計算し た值, $\square$ 印は試験体の曲げひび割れより求めた中立軸位置 $x_{n}$ であり, 圧縮域のコンクリートの全応力が有効圧縮強度に達するという仮定 に基づき, 図 12 に示すように載荷後の試験体から測定した。破線は 勒性指針式の見付け幅 $(=D / 2)$ を表す。ひび割れから求めた $x_{n}$ は上下 部材端の引張側で発生した曲げひび割れの長さを測定し, その長さ を部材せいから引いた值 $x_{n 1}, x_{n 2}$ の平均值 $x_{n}=\left(x_{n 1}+x_{n 2}\right) / 2$ とした。 $x_{n}$ の 算出にはひび割れを確認できた試験体のみ選定し, A2 試験体も含め た。なお，図の右軸は部材せいを表し，左軸と対応している。

軸力比 $\eta=0$ では, いずれの点も $x_{n}=50 \mathrm{~mm}(=D / 4)$ 程度と勒性指針 式の見付け幅 $D / 2$ の約半分の大きさとなった。 $x_{n}$ は軸力の増加に伴 い大きくなり, 軸力比 $\eta=0.4,0.6$ では勒性指針式とほぼ同等の $x$ $=100 \mathrm{~mm}(=D / 2)$ 程度となった。ここで, 中立軸位置 $x_{n}$ を部材せい $D$ と軸力比 $\eta$ を用いて近似すると, 以下に示寸関係が得られる。

$$
x_{n}=\frac{D}{4}(1+2 \eta)
$$

式(8)は図 11 の図中に実線で示しており, 他の点とよく適合して いる。特に，軸力比が小さい場合において，勒性指針式よりも式(8) のほうが実験值とよく対応している。

実際には，中立軸位置は主筋比やコンクリート強度，せん断スパ ン比によっても影響を受けると思われるが，勒性指針式ではアーチ 機構の圧縮縁から中立軸までの距離を部材長さとせいの関係により 簡略化して評価しており，十分な評価精度を有している。本研究で もこれに準ずる形で中立軸位置を評価した。軸力比や異なる主筋比 の場合において，若干異なることもあるが，勒性指針式と同等に評 価することが可能であると考えられる。

\section{3 軸力によるアーチ機構負担せん断力の上昇}

$\mathrm{A} 1 \sim \mathrm{A} 4$ シリーズ試験体および既往の文献におけるせん断補強筋 がない試験体の実験結果および, 式(2)に式(8)の中立軸位置考慮時の アーチ機構負担せん断力との比較を行った。式(8)の中立軸位置 $x_{n}$ を考慮したアーチ機構の負担せん断力 $V_{a}$ は式(9)で表される。簡略 化するため $R_{p}=0$ を仮定した。

$$
V_{a}=\frac{1}{2} v_{0} \sigma_{B} b x_{n} \sin 2 \theta
$$

ここで, アーチ機構の角度は式(10)によって求められる。

$$
\theta=\tan ^{-1} \frac{D-x_{n}}{L}
$$

図 13 に横補強筋がない試験体の実験值から式(2)を用いて逆算し たコンクリートの圧縮強度有効係数を, 図 14 に式(8)により計算さ れる中立軸位置 $x_{n}$ を用いた場合のコンクリートの圧縮強度有効係数 を示す。圧縮強度有効係数の算出にはいずれの図においても, 本実 験結果の A1〜A4 シリーズ試験体および既往の文献 ${ }^{33), 5), ~ 6), ~ 35)-38) ~ に お ~}$ いてせん断スパン比 1.0 以上で, せん断補強筋がない試験体の最大 耐力を用いた。白抜きは軸力のない試験体を表す。また, 図中には 勒性指針式で採用されている Nielsen ${ }^{39}$ によよって提案された式 $\left(v_{0}=0.7-\sigma_{B} / 200\right)$ と $\left.\mathrm{CEB}^{1}\right)$ 式 $\left(v_{0}=1.72 \sigma_{B}{ }^{-0.33}\right)$, 瀧口ら $\left.{ }^{3}\right)$ にって提案され た圧縮強度有効係数の下限值を表す式 $\left(v_{0}=0.85-\sigma_{B} / 340\right)$ も合わせて示 した。あまりひび割れていない本稿の試験体を対象とすることは, 曲げ強度時のコンクリート強度を求めていることとほぼ同等であり, 実際のひび割れた部材の有効圧縮強度係数よりも高くなるが，他の 試験体も含めた分布として評価した。

図 13 において, コンクリート強度が $60 \mathrm{~N} / \mathrm{mm}^{2}$ 以上の場合, 有効 係数は軸力がある試験体とない試験体で異なり, 軸力がある試験体 のほうが大きくなる。軸力によるせん断強度の上昇に伴い, 圧縮強 度有効係数も上昇しているといえる。コンクリート強度が $40 \mathrm{~N} / \mathrm{mm}^{2}$ 以下の場合においては, 0.6 から 1.6 の範囲でばらついているが, CEB 式は圧縮強度有効係数の下限值となる。一方, 図 14 では, 軸力のあ るなしに関わらず, 圧縮強度有効係数はコンクリートの圧縮強度に 比例して減少寸る傾向にある。ただし, コンクリート圧縮強度が小 さい場合においては, 圧縮強度有効係数が 1 を上回るものが多く,

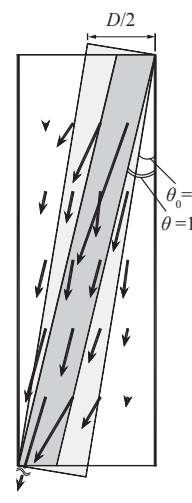

(a) $\mathrm{A} 1-0(\eta=0.0)$

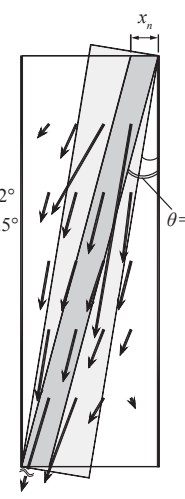

(b) $\mathrm{A} 1-2(\eta=0.2)$

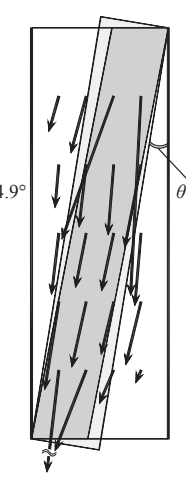

(c) A1-4 $(\eta=0.4)$

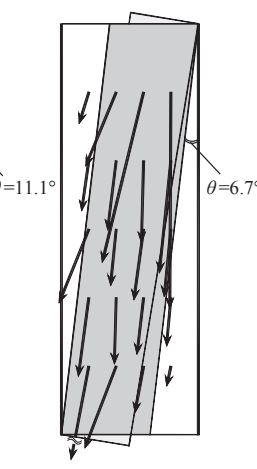

(d) A1-6 $(\eta=0.6)$
図 10 圧縮ストラットの角度

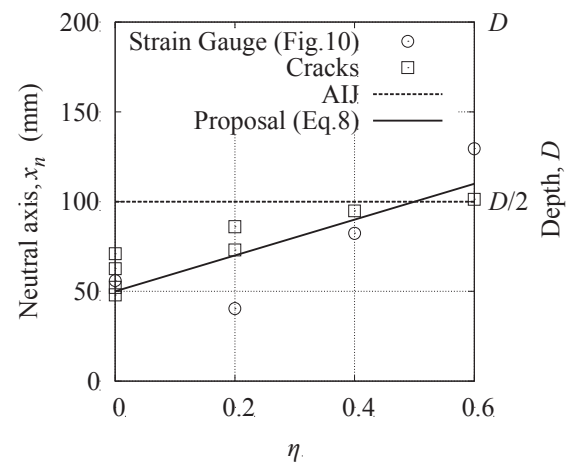

図 11 中立軸位置 $x_{n}$ (A1, A2 シリーズ試験体)

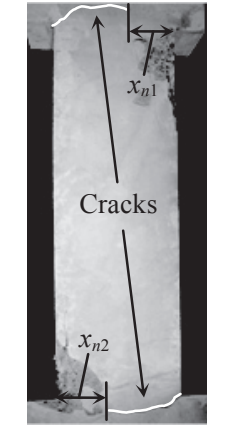

図 12 ひび割れか ら求めた中立軸位置 
梁については 2 倍近くなるものもある。軸力比が大きい試験体（図 中の左上破線円内）については, 勒性指針式と式(9)による計算值が ほぼ同じになるため, 計算される圧縮強度有効係数は図 13 と図 14 でほとんど変化しない。両図において, コンクリート圧縮強度が小 さい場合で，圧縮強度有効係数が 1 を上回った理由は，前述のせん 断補強筋がないことや，付着がないことなどで，せん断ひび割れが 少なかったこと，曲げ圧壊したことに起因していると考えられる。 そのため, 厳密にはひび割れて, トラス・アーチ機構が混在する実 際の柱梁部材とは異なる係数になっていることも考えられる。その 場合，せ几断破壊時の有効圧縮強度は実際には小さくなるが，す心゙ ての試験体の下限值をとる Nielsen 式を下回ることは考えにくいこ と, 他の結果が多数あることから, 本稿への影響は小さいと考え, そのまま扱うこととした。図 14 において, 瀧口らの式 ${ }^{3)}$ は実験值の

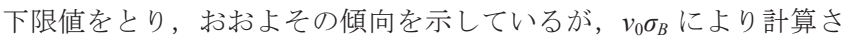
れる有効圧縮強度は，コンクリート圧縮強度が $120 \mathrm{~N} / \mathrm{mm}^{2}$ 以上にな ると減少することになることから超高強度コンクリート使用時には 問題が生じる。そこで, CEB 式に準ずる形で実験值の下限值をとる 圧縮強度有効係数として下式を定めた。求められる有効圧縮強度は $\mathrm{CEB}$ 式の約 1.3 倍となる。

$$
v_{0}=2.3 \sigma_{B}^{-0.33}
$$

また, 参考として同様の形で最小 2 乗法により求めた近似曲線 $\left(v_{0}=3.47 \sigma_{B}{ }^{-0.33}\right)$ を図中に示した。コンクリート強度が $40 \mathrm{~N} / \mathrm{mm}^{2}$ 以下の 場合に 1 以上になる。以上から, 式(9)において, 圧縮強度有効係数 として式(11)を用いれば，下限值としてアーチ機構に基づくせん断 強度算定において軸力の効果を考慮できるといえる。ただし, 式(9) はアーチ機構を対象としているため, 最大耐力がせん断ひび割れに よって決定しまうような，非常に高い軸力が作用する短スパンの部 材や超高強度コンクリートが用いられている部材には適用すること はできないと考えられる。

本稿では軸力に伴うせん断力上昇はアーチ機構の形状変化による ものであると結論づけ, 形状変化のメカニズムや有効圧縮強度の上 昇については考慮しなかった。軸力に伴う中立軸位置変化や有効圧 縮強度の増加は, 文献 34)によるモールクーロンの破壊基準の適用 によっても評価可能である。本稿の提案式は軸力によるせん断強度 上昇を評価する方法の一つとして勒性指針式に準ずる形で示したも のである。

\section{6. 軸力を受ける時のトラス機構負担せん断強度}

勒性指針式におけるトラス機構によるせん断強度 $V_{u}$ は式(12)によ って求められ，その時のトラス機構の角度 れる $\left(R_{p}=0\right.$ と仮定寸る $)$ 。式(13)で表されるトラス機構の角度が最小 になる時（ $\cot \phi=2$ の時），式(12)は式(2)と一致する。

$$
\begin{gathered}
V_{u}=p_{w e} \sigma_{w y} b_{e} j_{e} \cot \phi+\left\{v_{0} \sigma_{B}-\frac{\left(1+\cot ^{2} \phi\right) p_{w e} \sigma_{w y}}{\lambda}\right\} \frac{b D}{2} \tan \theta \\
\cot \phi= \begin{cases}2 & \left(p_{w e} \sigma_{w y} / v_{0} \sigma_{B} \leq \lambda / 5\right) \\
\sqrt{\frac{\lambda v_{0} \sigma_{B}}{p_{w e} \sigma_{w y}}-1} & \left(\lambda / 5 \leq p_{w e} \sigma_{w y} / v_{0} \sigma_{B} \leq \lambda / 2\right)\end{cases}
\end{gathered}
$$

また，軸力によるトラス機構の角度変化を考慮した式として，軸力

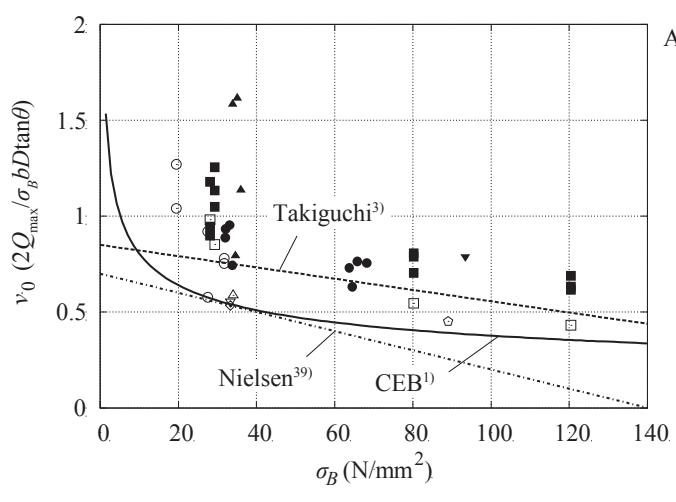

$\begin{array}{rr}\mathrm{A} 1-\mathrm{A} 4(\eta=0) & \square \\ \mathrm{A} 1-\mathrm{A} 4 & \mathbf{} \\ 3) & \bullet \\ 5) & \triangle \\ 6) & \nabla \\ 35) & \circ \\ 36) & \triangle \\ 37) & \nabla \\ 38) & \diamond\end{array}$

図 13 コンクリート圧縮強度有効係数

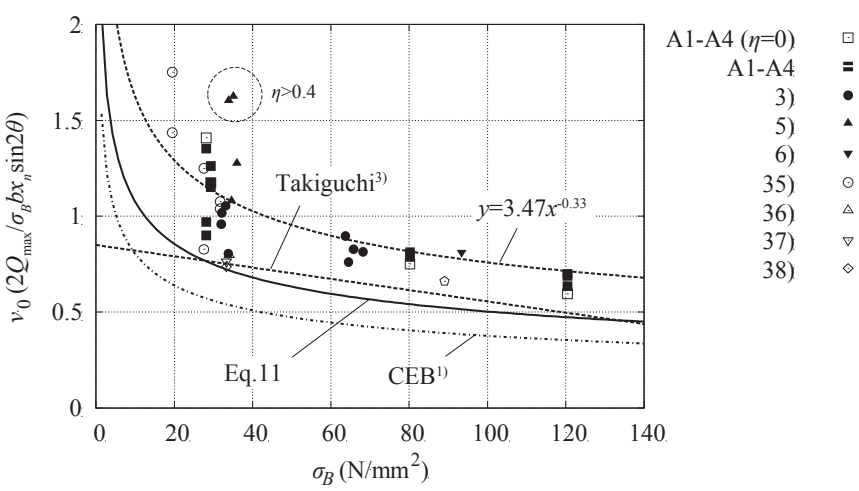

図 14 式(9)から計算したコンクリート圧縮強度有効係数

比が 0.6 程度においておおよそトラス機構の角度が 45 度になるとし た下式 ${ }^{40)}$ が示されている。

$$
\cot \phi=2-3 \eta
$$

式(14)では， $\cot \phi$ はラス機構の角度が大きくなると減少し，それに 伴って，せん断力 $V_{u}$ も減少することになる。

本研究では, 軸力が作用した場合のトラス機構の角度 $\phi$ を, $\mathrm{T}$ シリ 一ズの試験体の実験結果から求めた。トラス機構の角度は，鉄筋が トラス機構にのみ寄与する ${ }^{41)}$ と考え, せん断補強筋の引張力と主筋 の付着力の合力から求まるコンクリートの斜め圧縮力 $C_{t}$ の角度之 した。Tシリーズ試験体のせん断補強筋量 $p_{w e} \sigma_{w y} / v_{0} \sigma_{B}$ を $\lambda / 5$ 程度とし た理由は, 図 2 の 点を表し, アーチ機構の負担せん断力が最小と なることから, 斜め圧縮力の変化がトラス機構によってのみ生じる と考えたからである。また，図 1 からも， $p_{w e} \sigma_{w y} / v_{0} \sigma_{B}>\lambda / 2$ となるもの において，軸力の増加に伴いせん断力が上昇したものが多くないこ ともそのように考えた理由である。最大耐力時における各点の測定 ひずみから得られた圧縮力（せん断補強筋の引張力と主筋の付着力 の合力）とその角度を図 15 に図示する。図 15 中の矢印の大きさと 向きが圧縮力の大きさと角度を表し，值は各節点における斜め圧縮 力 $C_{t}$ を表す。なお, 部材端部危険断面位置の斜め圧縮力とその角度 中は曲げ変形の応力を負担していることから, 他の測定点と比較し て著しく大きかったため, 図からは除外した。図 16 に斜めひび割れ 領域におけるコンクリートの斜め圧縮力の釣り合い状態を示す。な お，式(14)により計算される T-0, T-3 試験体のトラス機構の角度 それぞれ 26.6 度と 42.3 度となる。

図 15 の斜め圧縮力 $C_{t}$ は, 両試験体とも端部圧縮領域のみやや小 さく,ばらつきが見られる。表 4 に図 15 のゴシックで示される斜め ひび割れ領域 ${ }^{1)}$ (部材両端部からヒンジ領域を想定した部材せい部 
分を抜いた領域と定義した）内の斜め圧縮力の平均值と平均角度を 示す。表 4 に示される T-3 試験体の斜め圧縮力は T- 0 試験体に比べ てやや小さくなっているが, 角度は T-0 試験体よりもやや増加して いる。これは, 斜め圧縮力を主筋の付着力から求めたことによると 思われる。すなわち, 軸力の増加により, 主筋の付着力が減少した ため, 付着力によって計算される斜め圧縮力が小さくなったと考え られる。したがって, このとき生じていたせん断補强筋による引張 力は T-0, T-3 試験体でほぼ同じであったことから, 表 4 に示される (平均) 斜め圧縮力は T-3 試験体のほうが小さくなり, (平均) 角度 は T-0 試験体の方が大きくなったと考えられる。軸力により軸方向 力がかぶりコンクリートの圧縮力によって負担された ${ }^{1)}$ と考えると, T-3 試験体に生じた斜め圧縮力は T- 0 試験体に比べて, ほぼ等しいか やや大きくなっていたと思われる(図 16 参照)。上記の理由により, 角度変化は僅少であると考えられることから, 本稿では軸力による 角度変化は無視することとする。なお, 計測により求めた角度の平 均值 (表 4 参照) は $\cot \phi=2$ の時の角度 (26.6 度)よりやや小さいが, 計測された圧縮力はある程度妥当なものであったといえる。

図 17 に式(13)と式(14)を用いて計算したせん断強度と実験值との 比を示す。※印は式(12)に式(13)を代入した場合であり，○印は式 (12)に式(14)を代入した場合である。破線は $\cot \phi$ を表しており, 右縦 軸に対応寸る。試験体は文献 ${ }^{5-27)}$ から横補強筋量が $p_{w e} \sigma_{w y} / v_{0} \sigma_{B}<\lambda / 5$ と なり, せん断強度が式(12)によって計算されるものを抽出した。卜 ラス機構の角度に式(14)を用いた場合, 適用範囲内となる軸力比 0.6 以下においては, 式(13)に比べてやや大きくなり, 実験值を過小評 価する。しかしながら, 軸力比が 0.6 よりも大きい場合には式(14) の適用範囲外となることから実験值が計算值を大きく上回るように なり，７倍程度上回るものもある。

以上から, 軸力によるトラス機構の負担せん断力への影響はなく, アーチ機構の負担せん断力のみが増えたと考えられる。つまり, 卜 ラス機構の角度は勒性指針式の式(13)によって評価するのが妥当で あるといえる。

\section{7. 提案せん断強度式の評価}

本研究の検討結果から, 軸力の影響を考慮したせん断強度式は軸 力によって変化する中立軸位置 $x_{n}$ を考慮した式(15)で表される。た だし，式(3)，(4)による計算值が式(15)よりも小さくなる場合には式

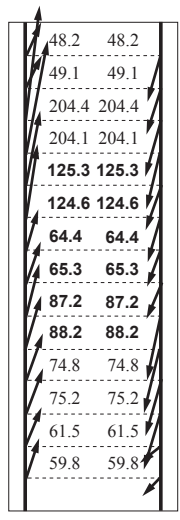

(a) T-0 試験体

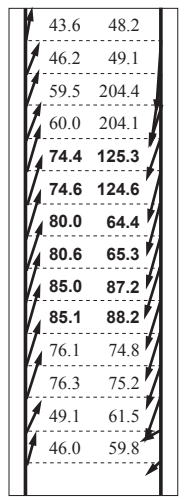

(b) T-3 試験体
図 15 コンクリートの斜め圧縮力
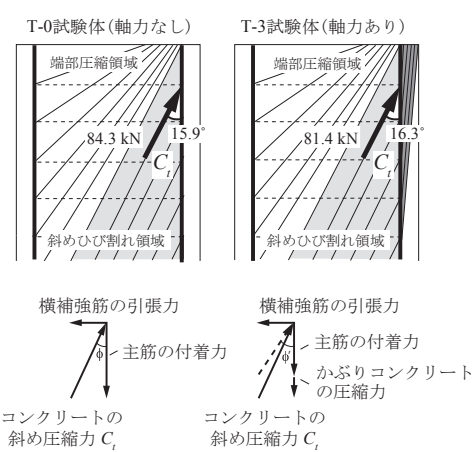

図 16 コンクリートの斜め圧縮力の 釣り合い
(3), (4)のうち小さい方の值をせん断強度とする。式からわかるよう に, アーチ機構による負担圧縮応力は勒性指針式と同じく, トラス 機構により負担されない圧縮応力分として決定される。

$$
V_{u}=\mu p_{w e} \sigma_{w y} b_{e} j_{e}+\left(v_{0} \sigma_{B}-\frac{5 p_{w e} \sigma_{w y}}{\lambda}\right) \frac{b x_{n}}{2} \sin 2 \theta
$$

式(15)を用いて算出した既往の文献 $\left.\left.{ }^{5-27)}, 35-38\right), 42-44\right)$ の柱梁試験体のせ ん断応力度と実験值の関係を図 18 に示す。なお, コンクリートの圧 縮強度有効係数には式(11)を用いた。点種の違いはせん断補強筋を 配しない試験体と梁，柱の試験体を表す。破線は土 $20 \%$ に対応する 直線である。若干過小評価している試験体もあるが，軸力比，コン クリート強度及びせん断スパン比に関わらず式(15)の計算值はほぼ 実験值 $\pm 20 \%$ にあり，精度よく予測できている。

式(15)を用いて計算した柱試験体のせん断強度，実験值の比と軸 力比の関係を図 19 に示す。せん断補強筋のない試験体, 式(15), 式 (3)，式(4)によりせん断強度が決定した試験体に分けて示している。 破線はその回帰式である。図 1(b) と比較すると, せん断補強筋量が 少ない試験体（せん断強度が式(15)により決定される試験体）のば らつきが小さくなり，精度もよくなった。ただし，せん断補強筋が ない試験体は值が大きくなっており, せん断補強筋のある通常の柱 とは異なる応力状態になっていることが過小評価となる原因である と考えられる。この傾向は鞋性指針 ${ }^{1)}$ においても指摘されている。

\begin{tabular}{|c|c|c|}
\multicolumn{1}{|c|}{ 表 4 コンクリートの斜め圧縮力と角度の平均值 } \\
\hline $\begin{array}{c}\mathrm{T}-0 \text { 試験体 } \\
(\eta=0.0)\end{array}$ & $\begin{array}{c}\mathrm{T}-3 \text { 試験体 } \\
(\eta=0.3)\end{array}$ \\
\hline$Q_{\max }(\mathrm{kN})$ & 179 & 209 \\
\hline 平均斜め圧縮力 $C_{t}(\mathrm{kN})$ & 84.3 & 81.4 \\
\hline 平均角度 $\phi\left(^{\circ}\right)$ & 15.9 & 16.3 \\
\hline
\end{tabular}

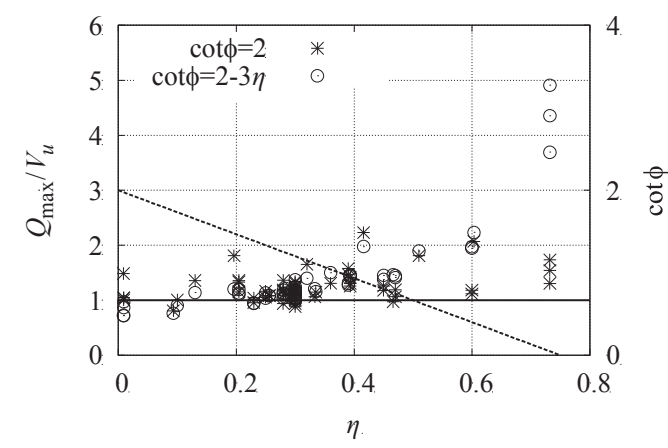

図17 $\cot \phi$ における軸力比の影響

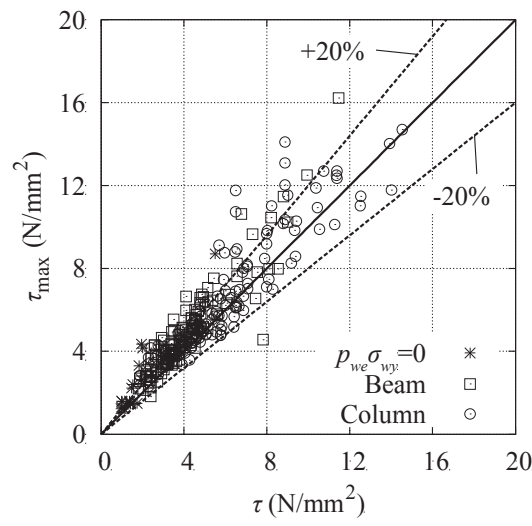

図 18 せん断応力度の比較 $\left(v_{0}=2.3 \sigma_{B}^{-0.33}\right)$ 


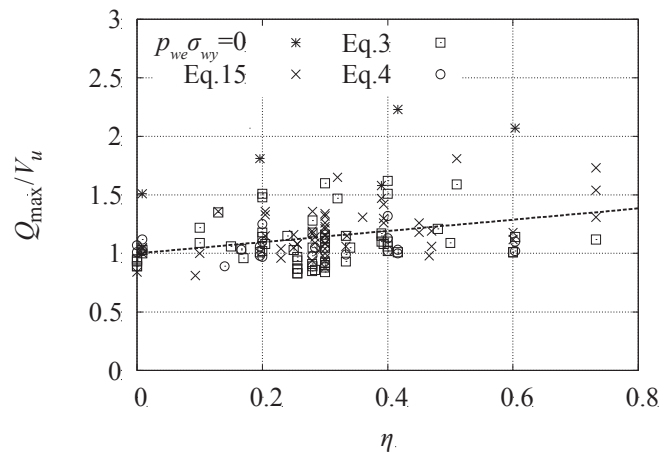

図 19 せん断強度と軸力比

本稿で提案した中立軸位置を求める式(8)やコンクリートの有効 圧縮強度を求める式(11)は理論解によって得られていないが，これ らの数值は学会の勒性指針式でも理論的に得られておらず, 簡略化 して評価している。したがって, 本稿の提案式が有する理論性は, 勒性指針式とそれほど乘離しているものではないと考えられる。よ り論理的な提案式とするため, 軸力が圧縮ストラット幅に与える影 響を理論的に導くことが今後の検討課題である。また，本稿のせん 断強度評価はすべて降伏ヒンジ・潜在ヒンジを計画せず，ヒンジ回 転角 $R_{p}=0$ として行ったものであるため, ヒンジの回転角想定時にお けるせん断強度評価が妥当なものであるかについても検討する余地 がある。

\section{8. まとめ}

本研究では, アーチ・トラス機構に基づく勒性保証型設計指針の せん断強度式において, 軸力が及ぼす影響を考察するため, 圧縮軸 力を主なパラメータとしたせん断補強筋のない鉄筋コンクリート柱 部材の載荷実験を行った。実験結果の考察により, 軸力を考慮した せん断強度式の提案を行い, せん断強度式に関する以下の知見を得 た。

(1) アーチ機構の圧縮ストラットの角度は軸力の影響を大きく受 け, 軸力の増加により角度が小さくなる。それに伴い圧縮ス卜 ラットの幅（中立軸長さ）は大きくなり, 軸力がない場合は部 材せいの $1 / 4$, 高軸力の場合は部材せいの $1 / 2$ 程度の幅となる。

(2) 軸力比の増加はトラス機構の負担せん断力の増加には寄与し ない。

（3）勒性保証型設計指針のせん断強度式において, 軸力増加による アーチ機構の圧縮ストラット幅の変化を考慮し, 提案したコン クリート圧縮強度有効係数を用いることで, 柱梁部材のせん断 強度は軸力比に関わらず精度よく評価できる。

\section{謝辞}

本研究の実験にあたり，高周波熱錬株式会社，BASF ポゾリス株式 会社，株式会社デイ・シイの協力を得ました。ここに記して謝意を 表します。

\section{参考文献}

1) 日本建築学会: 鉄筋コンクリート造建物の勒性保証型而震設計指針・同解 説, 1997

2) 日本建築学会: 鉄筋コンクリート造建物の終局強度型而震設計指針・同解 説, 1990
3) 㴰口克己, 西村康志郎: せん断補強筋のない $\mathrm{RC}$ 柱部材の斜め圧縮力伝達 能力, 日本建築学会構造系論文集, No.534, pp.113-119, 2000.8

4) 白石一郎, 高木仁之, ジェームズイルサ : RC 造部材のトラスアーチ理論に おけるトラス機構角度に関寸る一考察, 日本建築学会構造系論文集, No.548, pp.115-122, 2001.10

5）黒正清治，松崎育弘，林静雄，小林克巳，偉川哲光，熊谷仁志，武居泰，夫 拓量: 高強度せん断補強筋を用いた RC 柱に関する実験研究: その 1 実験概 要及び荷重・変形関係, 日本建築学会大会学術講演梗概集 C, 構造 II, pp.483-484, 1987.8

6) 来田義弘, 坂口昇, 河内武, 香田伸次, 野崎次男, 九々正武: 超高強度コン クリート造柱の曲げせん断実験（その 1）実験概要, 日本建築学会大会学 術講演梗概集 C, 構造 II, pp.697-698, 1988.10

7) 柴田正隆, 塚本尚由, 中澤淳, 林優, 白石環, 山本昇, 倉本洋, 南宏一: 13000 キロ級のせん断補強筋を用いた $40 \mathrm{~cm}$ 角断面の $\mathrm{RC}$ 柱のせん断破壊性 状（その 1) 実験概要, 日本建築学会大会学術講演梗概集 C, 構造 II, pp.693-694, 1989.10

8) 中澤淳, 塚本尚由, 林優, 柴田正隆, 白石環, 山本昇, 倉本洋, 南宏一: 13000 キロ級のせん断補強筋を用いた $40 \mathrm{~cm}$ 角断面の $\mathrm{RC}$ 柱のせん断破壊性 状（その 3) 破壊性状, 日本建築学会大会学術講演梗概集 C, 構造 II, pp.697-698, 1989.10

9) 大芳賀義喜, 田中礼治, 小倉弘一郎: 高強度鉄筋の開発に関寸る研究: そ の 14一柱のせん断実験, 日本建築学会大会学術講演梗概集 C, 構造 II, pp.951-952, 1990.10

10) 細矢博, 岡田恒男, 安井健治, 安倍勇, 北川良和, 舟山勇司: RC 部材の耐力 と破壊モードに及ぼすひずタ速度の影響, 日本建築学会大会学術講演梗概 集 C, 構造 II, pp.165-166, 1991.9

11）瀬尾正幸，野口博，井上範夫，北山和弘，丸田誠，二村有則：高強度材料を 用いた RC 柱のせん断性状に関寸る研究 (その 1. 実験概要と結果)，日本 建築学会大会学術講演梗概集 C, 構造 II, pp.627-628, 1992.8

12) 板倉康久, 安居功二, 張富明, 益尾潔: 高強度コンクリートと高強度せん 断補強筋を用いた RC 柱のせん断耐力と変形性能に関する実験的研究，コ ンクリート工学年次論文報告集, Vol.14, No.2, pp.291-296, 1992.6

13）井上章男, 西村泰志, 倉本洋: 高強度せん断補強筋を用いた鉄筋コンクリ 一ト柱のせん断破壞性状, 日本建築学会大会学術講演梗概集 C, 構造 II, pp.635-636, 1992.8

14) 桑田裕次, 南宏一: 480 キロ級の高強度コンクリートを用いた $\mathrm{RC}$ 柱のせん 断耐力に及ぼす作用軸力比の影響，コンクリート工学年次論文報告集， Vol.17, No.2, pp.857-862, 1995.6

15）高見信嗣, 吉岡研三, 超高強度コンクリートを用いた RC 柱のせん断強度 に関する実験研究（軸力比，横補強筋，載荷方向の影響）, 日本建築学会大 会学術講演梗概集 C-2, 構造 IV, pp.25-26, 1997.7

16) 金杉英輝, 中沢淳, 山下祐司, 宮腰昌平, 桑田裕次, 南宏一: $8000 \mathrm{kgf} / \mathrm{cm}^{2}$ 級 の高強度せん断補強筋を用いた鉄筋コンクリート柱のせん断破壊性状に 関する実験的研究（その 1)，日本建築学会大会学術講演梗概集 C-2, 構造 IV, pp.1-2, 1997.7

17) 宇和田満之, 中沢淳, 山下祐司, 宮腰昌平, 桑田裕次, 南宏一: $8000 \mathrm{kgf} / \mathrm{cm}^{2}$ 級の高強度せん断補強筋を用いた鉄筋コンクリート柱のせん断破壊性状 に関する実験的研究（その 2), 日本建築学会大会学術講演梗概集 C-2, 構 造 IV, pp.3-4, 1997.9

18) 大山博, 中沢淳, 山下祐司, 宮腰昌平, 桑田裕次, 南宏一: $8000 \mathrm{kgf} / \mathrm{cm}^{2}$ 級の 高強度せん断補強筋を用いた鉄筋コンクリート柱のせん断破壊性状に関 する実験的研究 (その 3), 日本建築学会大会学術講演梗概集 C-2, 構造 IV, pp.5-6, 1997.7

19）中澤淳, 山下祐司, 宮腰昌平, 桑田裕次, 南宏一: 高強度コンクリートを用 いた鉄筋コンクリート柱のせん断破壊性状に関する実験的研究（その 1）， 日本建築学会大会学術講演梗概集 C-2, 構造 IV, pp.337-338, 1998.7

20）熊谷仁志，中澤春生，塚越英夫，黒瀬行信，矢部喜堂：超高強度コンクリー 卜構造 $\left(\mathrm{Fc}=120 \mathrm{~N} / \mathrm{mm}^{2}\right)$ の開発: その 2 柱の曲げせん断実験, 日本建築学会 大会学術講演梗概集 C-2, 構造 IV, pp.609-610, 2000.7

21）堀伸輔, 岩岡信一, 渡邊朋之, 青田晃治, 山本憲一郎: 超高強度鉄筋コンク リート構造の柱部材実験: その 1 実験概要, 日本建築学会大会学術講演梗 概集 構造系 (C-2), pp.415-416, 2002.8

22）岩岡信一, 青田晃治, 渡邊朋之, 堀伸輔, 山本憲一郎: 超高強度鉄筋コンク リート構造の柱部材実験: その 2 実験結果の検討, 日本建築学会大会学術 講演梗概集 構造系 (C-2), pp.417-418, 2002.8

23) 木村暁子, 丸田誠: 高強度鉄筋コンクリート柱の高軸力下におけるせん断 
性状に関寸る実験的研究，コンクリート工学年次論文報告集, Vol.24, No.2, pp.751-756, 2002.6

24) 半田士昌, 河合繁, 香取慶一, 林靜雄: RC 造柱の損傷過程に軸方向及び断 面形状が及ぼす影響: その 1 実験概要及び実験結果, 日本建築学会大会学 術講演梗概集 C-2, 構造 IV, pp.131-132, 2003.7

25) 片岡隆広, 今里久明, 市川昌和, 加藤真人, 松浦恒久, 佐藤武: 超高強度材 料を用いた鉄筋コンクリート造柱部材の構造性能に関する実験研究（その 3）一定軸力下での曲げせん断性状, 日本建築学会大会学術講演梗概集 C-2, 構造 IV, pp.497-498, 2004.7

26) 久保田篤史, 大浜設志, 矢野秀樹, 林靜雄: 軸力を変動要因とした RC 柱の 損傷過程におけるせん断力の評価に関する実験研究: その 1 実験概要及び 実験結果, 日本建築学会大会学術講演梗概集 C-2, 構造 IV, pp.325-326, 2007.7

27) 篠原保二, 久保田透, 林靜雄: 超高強度コンクリート柱のひび割れ挙動 (そ の 1 実験概要および実験結果），日本建築学会大会学術講演梗概集 C-2, 構造 IV, pp.605-606, 2008.7

28) 日本建築学会 : 鉄筋コンクリート構造計算規準・同解説, 1999

29) 久田昌典, 日比野陽, 篠原保二, 林靜雄: 補強筋量が少ない RC 造柱のせん 断強度に及ぼす軸力の影響, コンクリート工学年次論文集, Vol. 33, No. 2, pp.115-120, 2011.7

30) 白石一郎, 宮脇毅, 高木仁之: 主筋付着の有無が RC柱のせん断挙動に及ぼ す影響, コンクリート工学年次論文集, Vol.24, No.2, pp.871-876, 2002.6

31) 白石一郎, 高木仁之: $\mathrm{RC}$ 柱のトラスアーチ理論におけるアーチ機構のせん 断挙動, コンクリート工学年次論文集, Vol.25, No.2, pp.205-210, 2003.7

32) Building Code Requirements for Reinforced Concrete (ACI 318-08) and Commentary, ACI Committee 318, 2008

33) 市之瀬敏勝: RC 部材の危険断面近傍でのトラス機構, 日本建築学会構造系 論文集, No.475, pp.129-135, 1995.9

34）花井伸明, 平林聖尊, 市之瀬敏勝: モールクーロンの破壊基準を用いた $\mathrm{RC}$ 部材のせん断挙動評価, コンクリート工学論文集, Vol.19, No.1, pp.1-9, 2008.1

35) 福原正志，黒正清治：鉄筋コンクリート部材における高強度せん断補強筋
の補強効果に関する実験研究一はりの曲げせん断実験一, 日本建築学会論 文報告集, No.320,pp.12-20,1982.10

36）黑正清治，福原正志：高強度せん断補強笳を用いた鉄筋コンクリート梁・ 柱の力学的挙動に関する実験研究（その 1 梁のせん断終局強度）, 日本 建築学会関東支部研究報告集, 構造系, No.47,pp.201-204, 1976.7

37) 植松卓二, 高木仁之, 新田隆雄, 奥出久人, 狩野芳一: 高強度せん断補強筋 を用いた RC はりのせん断実験: その 1一降伏点強度の影響 (実験概要およ び結果），日本建築学会大会学術講演梗概集 C, 構造 II, pp.711-712, 1989.9

38）坂口昇, 鈴木忠彦, 河内武, 首藤恵治, 来田義弘, 九々正武: 超高強度鉄筋 コンクリート造短スパン梁の曲げせん断耐力実験（その2) せん断特性, 日 本建築学会大会学術講演梗概集 C, 構造 II, pp.69-70, 1987.8

39) Nielsen, M.P.: Limit Analysis and Concrete Plasticity, Prentice Hall, 420pp.

40) 倉本洋, 渡辺史夫, 南宏一, 西村泰志, 村上秀夫: 部材に対寸る NewRC せ ん断強度式の耐力予測精度, 日本建築学会大会学術講演梗概集大会 $\mathrm{C}$, 構 造 II, pp.705-706, 1993.7

41) 嘉村武浩, 石川裕次, 浜本学, 小谷俊介, 青山博之: 鉄筋コンクリート梁部 材の変形能に関寸る実験的研究，コンクリート工学年次論文報告集, Vol.15, No.2, pp.335-340, 1993.6

42）榎本浩之, 慶祐一, 柿田芳久, 渡辺史夫, 六車熙: 超高強度鉄筋コンクリー トを用いた梁のせん断強度に関する研究（その $1 . \mathrm{f}_{\mathrm{c}}{ }^{\prime}=1200 \mathrm{~kg} / \mathrm{cm}^{2}$ に関する 実験）, 日本建築学会大会学術講演梗概集 C, 構造 II, pp.287-288, 1990.9

43）慶祐一, 榎本浩之, 渡辺史夫, 六車熙: 高強度鉄筋コンクリートを用いた 梁のせん断強度に関する研究（その $1 . \mathrm{f}_{\mathrm{c}}{ }^{\prime}=600 \mathrm{~kg} / \mathrm{cm}^{2}, 800 \mathrm{~kg} / \mathrm{cm}^{2}$ に関する実 験)，日本建築学会大会学術講演梗概集 C, 構造 II, pp.269-270, 1991.8

44）酒井崇行, 荒井康幸, 溝口光男, 山田基彦, 大沼忠孝, 冨士和成, 河原俊哉: $600 \mathrm{~N} / \mathrm{mm}^{2}$ 級高強度せん断補強筋を用いた鉄筋コンクリート梁のせん断補 強効果, 日本建築学会北海道支部研究報告集, No.70, pp.61-64, 1997.3

（2011年 9 月10日原稿受理，2012年 4 月10日採用決定） 